\title{
Paleoclimate Reconstruction during Mamu Formation (Cretaceous) Based on Clay Mineral Distributions
}

\author{
${ }^{1}$ Odoma,A.N., ${ }^{2}$ Obaje, N.G., ${ }^{1}$ Omada, J.I., ${ }^{1}$ Idakwo,S.O. \& ${ }^{3}$ Erbacher, J. \\ ${ }^{1}$ Department of Earth Sciences, Kogi State Univeristy,P.M.B.1008, Anyigba, Kogi State,Nigeria. \\ ${ }^{2}$ Department of Geology, Ibrahim Badamasi Babangida University, Lapai, Niger State, Nigeria. \\ ${ }^{3}$ Federal Institute for Geosciences and Natural Resources, (BGR), Hannover, Germany.
}

\begin{abstract}
Paleoclimate was reconstructed by the clay mineral assemblages within the age of Cretaceous (Campanian - Maastrichtian) of the Mamu Formation. To compare with clay mineral assemblages in this formation, selected samples were collected from sections along the road cuts from the King Petrol Station up the Miliken Hills and at the left bank of River Ekulu near the bridge to Onyeama mine, around Iva Valley and along Enugu Port-Harcourt road in Enugu State. Collected samples were prepared using standard clay mineral methodology. Their identification was made on X-Ray diffractographs, Kaolinite covered a range of $22-45 \%$, its variation style in this formation could be a marker of climate changes from wet to dry which is supported by the lithological changes. Illite percentage varies from 5-10 and increases from Enu.1.1-1.5 to Enu.2.1-2.5. This may be due to dominant dry climate. Montmorrilonite ranges from $7-10 \%$ and its presence is due to terrestrial depositional condition. It seems thus, the present results can be indicated a possible procedure for ancient climate changes evaluation.
\end{abstract}

Keywords: (Clay minerals, Paleoclimate, XRD, Mamu formation)

\section{Introduction}

Clay is formed either as a product of the chemical weathering of pre-existing granitic rocks and feldspar minerals, particularly in warm tropical and subtropical regions of the world or as a result of the hydrothermal alteration of granitic rocks.

Chemically, clays are hydrous aluminum silicates, ordinarily containing impurities, for example potassium, sodium, calcium, magnesium, or iron, in small amounts, and are characterized by sheet silicate structures of composite layers stacked along the c-axis (Grim, 1968). Clay has a wide variety of physical characteristic such as plasticity, shrinkage under firing and under air-drying, fineness of grain, colour after firing, hardness, cohesion, and capacity of the surface to take decoration.

Detailed accounts on the geology, stratigraphy and economic potentials of the Lower Benue Trough have been reported (Simpson, 1954; Reyment, 1965; Kogbe and Okeudu, 1978; Agumanu, 1989; Akande et al., 1989, 1992; Uma, 1998; Zarborski, 1998).

Several clay occurrences have been investigated and reported in Nigeria and have been mined since the Stone Age, which are indispensable in architecture, in industry, and agriculture. Today they are among the most important minerals used by manufacturing and environmental studies. Globally, clay has a wide spread occurrence. In Nigeria, clay is widely distributed though not always found in sufficient quantity or suitable quality for modern industrial purposes. More than 80 clay deposits have been reported from all parts of the country. For instance, clay deposits occur in Abak, Akwa Ibom State, Uruove near Ughelli in Delta State, Ifon in Ondo State, Mokola in Oyo State, Sokoto in Sokoto State, Gombe in Gombe State, Dangara in Niger State, Umuahia in Abia State, Onitsha in Anambra State and Kutigi in Niger State. e.t.c.

These occurrences vary from the lateritic and residual profiles derived from the weathering of basement rocks (Elueze and Bolarinwa, 1995, 2001; Nton and Elueze, 2005) to those of the sedimentary units and alluvial bodies within the various depositional basins and along the major fluvial channels (Emofurieta et al, 1994, Elueze et al, 1999). The interest in these studies is hinged on the effective exploitation of the local raw materials for sustainable economic growth and creation of employment opportunities (Elueze, 1998).

Despite these studies, the paleoclimatic reconstructions of clay mineral assemblages during their deposition within the Lower Benue trough in Southeastern Nigeria during Mamu Formation are still poorly understood. The main aim of this study is to investigate the clay mineral assemblages to reconstruct paleoclimate during their deposition in southeastern Nigeria during Mamu Formation, with special focus to the mineralogical composition.

\section{Location And Geological Description}

The study area falls within the geographic coordinates of Latitudes $\mathrm{N} 06^{\circ} 28^{\prime} 09^{\prime \prime}$ and $\mathrm{N} 06^{\circ} 26^{\prime} 05^{\prime \prime}$ north of the Equator and longitudes E007 $28^{\prime} 16^{\prime \prime}$ and E $007^{\circ} 32^{\prime} 22^{\prime \prime}$ East of the Greenwich Meridian, The study 
forms part of the Mamu Formation which is best exposed at the Miliken Hills in Enugu, with well-preserved sections along the road cuts from the King Petrol Station up the Miliken Hills and at the left bank of River Ekulu near the bridge to Onyeama mine, around Iva Valley and along Enugu Port Harcourt in Enugu State, Southeastern Nigeria (Fig.1).Clay mineral distribution was studied in major clay units within the age of Cretaceous (Campanian - Maastrichtian) of the Mamu Formation (Figure 2) in different geological situation, that occurred within the Lower Benue Trough, Southeastern Nigeria, Nigeria (Figure 3). This unit is described briefly.

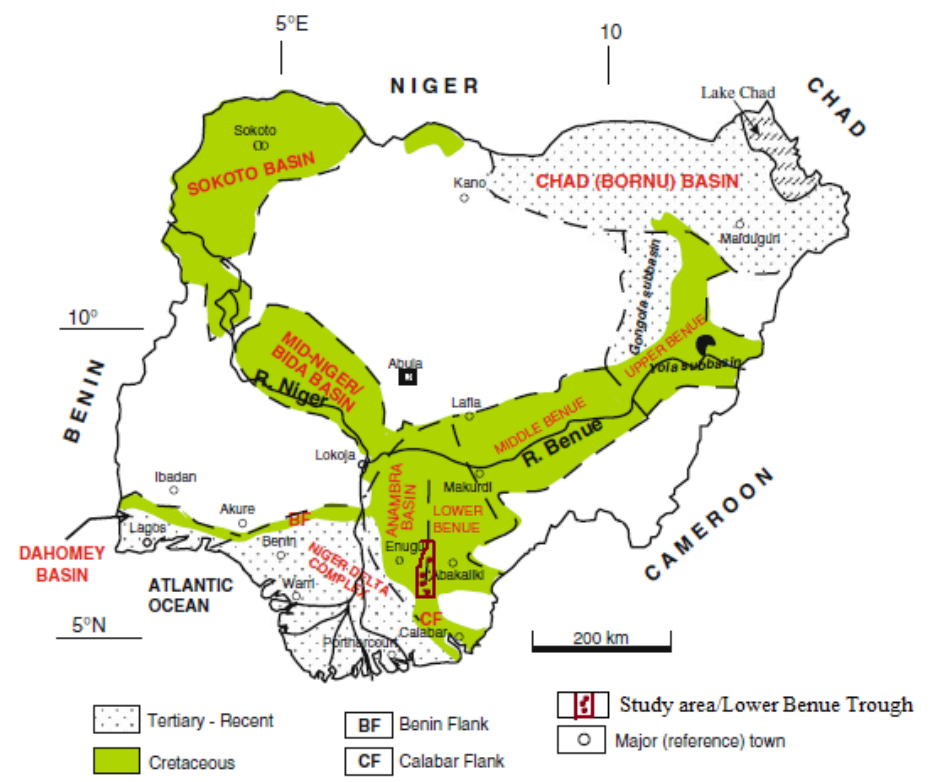

Fig. 1: The Location of the studied Trough (Modified after Obaje. 2009)

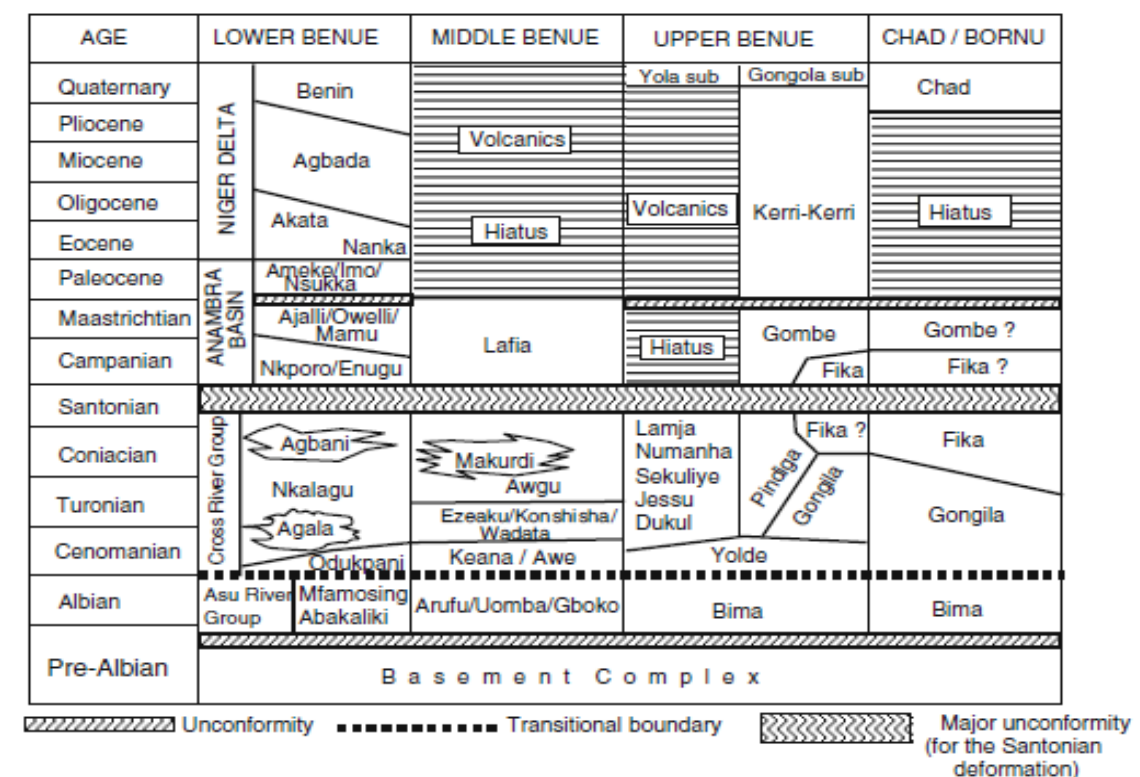

Fig. 2: Mesozoic-Cenozoic Stratigraphic correlation chart of the Benue Trough

Sedimentation in the Lower Benue Trough commenced with the marine Albian Asu River Group, the Asu River Group in the Lower Benue Trough comprises the shales, limestones and sandstone lenses of the Abakaliki Formation in the Abakaliki area and the Mfamosing Limestone in the Calabar Flank (Petters, 1982). The marine Cenomanian - Turonian Nkalagu Formation (black shales, limestones and siltsones) and the interfingering regressive sandstones of the Agala and Agbani Formations rest on the Asu River Group. Mid-Santonian deformation in the Benue Trough displaced the major depositional axis westward which led to the formation of the Anambra Basin. Post-deformational sedimentation in the Lower Benue Trough, therefore, constitutes the Anambra Basin. Sedimentation in the Anambra Basin commenced with the Campanian-Maastrichtian marine and paralic shales of the Enugu and Nkporo Formations, overlain by the coal measures of the Mamu Formation. 
The fluviodeltaic sandstones of the Ajali and Owelli Formations lie on the Mamu Formation and constitute its lateral equivalents in most places. The coal-bearing Mamu Formation and the Ajali Sandstone accumulated during this epoch of overall regression of the Nkporo cycle. The Mamu Formation occurs as a narrow strip trending north-south from the Calabar Flank, swinging west around the Ankpa plateau and terminating at Idah near the River Niger. The Nsukka Formation and the Imo Shale mark the onset of another transgression in the Anambra Basin during the Paleocene. The shales contain significant amount of organic matter and may be a potential source for the hydrocarbons in the northern part of the Niger Delta. In the Anambra Basin, they are only locally expected to reach maturity levels for hydrocarbon expulsion. The Eocene Nanka Sands mark the return to regressive conditions. The Nanka Formation offers an excellent opportunity to study tidal deposits. Well-exposed, strongly assymetrical sandwaves suggest the predominance of flood-tidal currents over weak ebbreverse currents. The presence of the latter are only suggested by the bundling of lamine separated from each other by mud drapes reflecting neap tides. A good outcrop of the Nanka Formation is the Umunya section, 18 $\mathrm{km}$ from the Niger Bridge at Onitsha on the Enugu - Onitsha Expressway.

\section{Materials And Methods Of Study}

To study clay mineral assemblage, the selected samples were subjected to different processes: grinding and homogenization. Grind the dried sample thoroughly with the mortar and pestle. The particles should be much finer than $0.062 \mathrm{~mm}$ to avoid fractionation of the minerals. The finer the powder the greater the opportunity for obtaining an adequate number of particles with random orientation and less likely the surface roughness will reduce low-angle intensities. The powdered sample was weighed and tested using a PW 1840 automated powder diffraction equipped with a $\mathrm{Cu}-\mathrm{K} \alpha$ radiation source, inbuilt standards, Peak/width and a detector. The diffraction pattern was obtained with the aid of a computer, while the $2 \Theta, d$ - values and peak intensities yielded by the powder patterns were used to identify the minerals.

A quantitative determination of the mineralogical property of the clay samples using X-ray diffraction were carried out at BGR laboratory, Hannover, Germany.

\section{Results And Discussion}

\section{Mineralogy}

Petrographic examinations and interpretation of diffractograms (Figures 3 and 4) show that Kaolinite is the dominant clay mineral in the Enugu clay of the Mamu Formation. It constitutes about $28 \%$ Kaolinite and $43 \%$ Quartz respectively. A sample of the results obtained from the X-ray diffraction analysis is presented in figures 3 and 4 below. A summary of the XRD results of the mineralogical analysis are presented in Table 1 . The XRD results of the mineralogical analysis showed the mineralogical assemblages of the sample. The major minerals present have been indicated against the diagnostic peaks as shown in figures 3 and 4 .

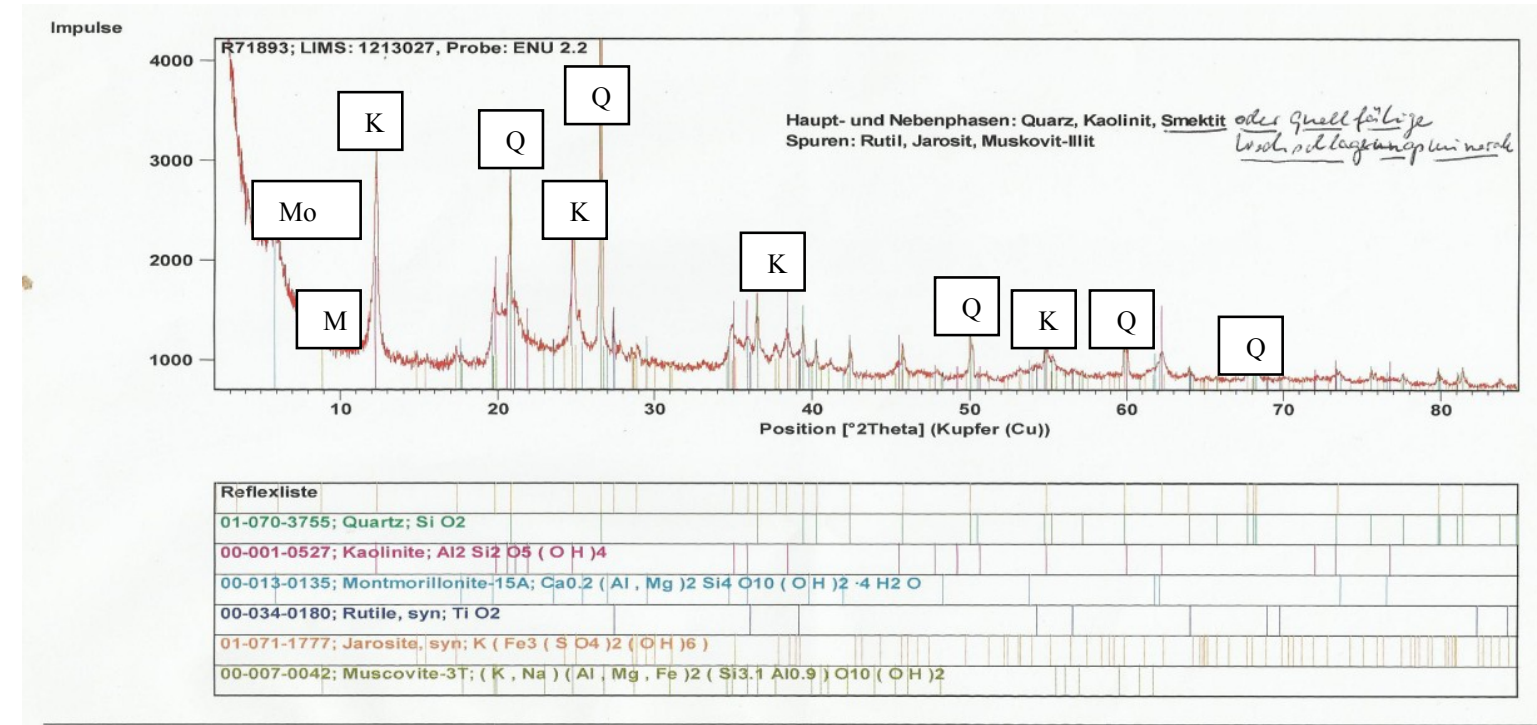

Mo- Montmorillonite, M- muscovite, Q- Quartz, K-Kaolinite.

Fig.3: Diffractogram of the Clay (Enu 2.2) from Enugu, Southeastern Nigeria 


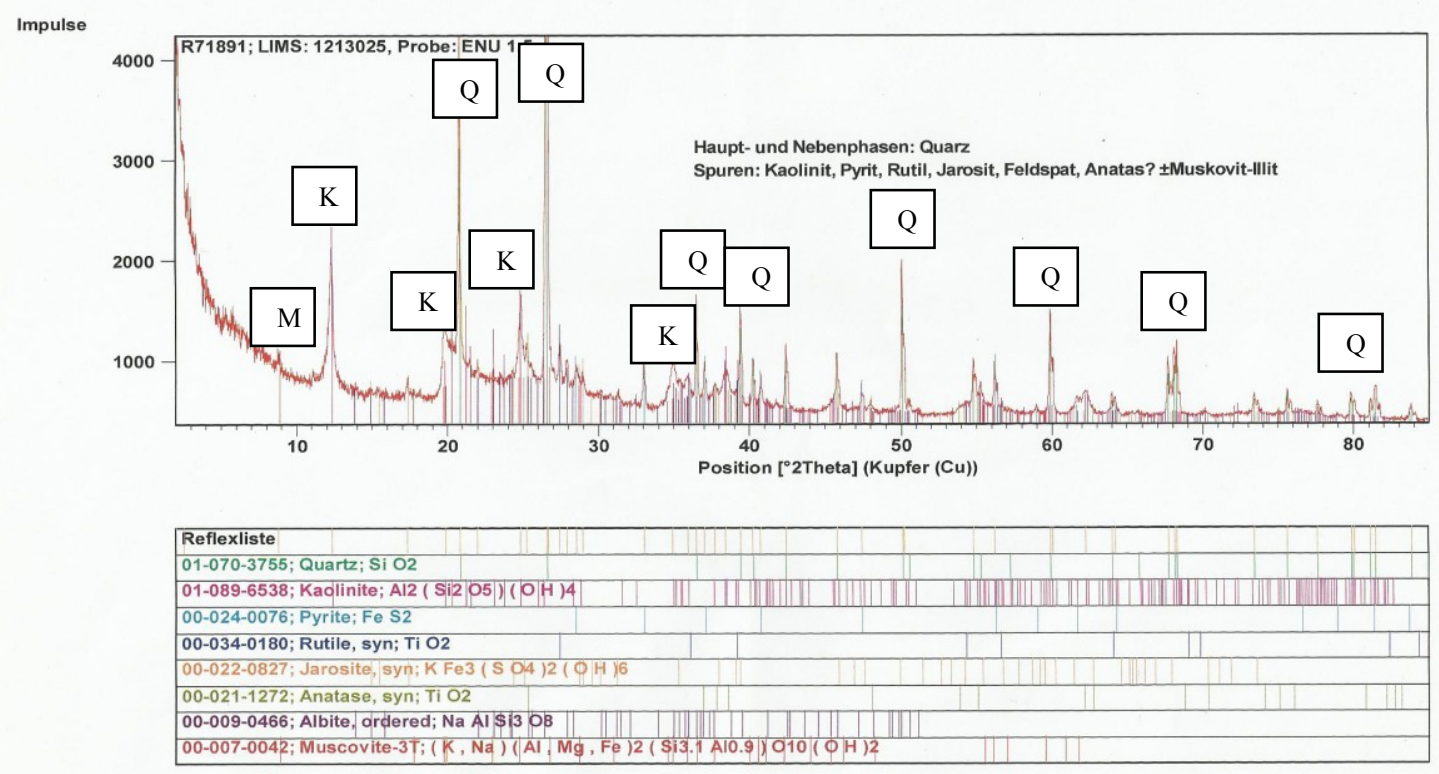

\section{M- muscovite, Q- Quartz, K-Kaolinite}

\section{Fig.4: Diffractogram of the Clay (Enu 1.5) from Enugu, Southeastern Nigeria}

Table 1: Mineralogical Composition of the clay sample from Southeastern Nigeria

\begin{tabular}{|l|l|l|l|l|l|l|l|l|l|l|}
\hline Minerals & $\begin{array}{l}\text { Enu.1. } \\
1\end{array}$ & Enu1.2 & $\begin{array}{l}\text { Enu1. } \\
3\end{array}$ & $\begin{array}{l}\text { Enu1. } \\
4\end{array}$ & Enu1.5 & Enu2.1 & Enu2.2 & Enu2.3 & Enu2.4 & Enu2.5 \\
\hline Quartz & 46 & 45 & 42 & 50 & 45 & 25 & 40 & 40 & 42 & 41 \\
\hline Kaolinite & 25 & 27 & 28 & 30 & 25 & 45 & 25 & 25 & 23 & 22 \\
\hline Pyrite & 5 & 5 & - & 3 & 5 & - & - & - & - & - \\
\hline Rutile & 8 & 5 & 8 & 8 & 6 & - & 10 & 8 & 8 & 5 \\
\hline Jarosite & 5 & 4 & 7 & 2 & 4 & - & 5 & 8 & 8 & 7 \\
\hline Feldspar & - & - & - & - & - & - & - & - & - & - \\
\hline Anatase & 6 & 7 & 7 & 4 & 4 & - & - & - & 5 & 6 \\
\hline Muscovite-Illite & - & - & - & - & 5 & - & 10 & 8 & 7 & 5 \\
\hline Smectit/Mixed Layer & - & - & - & - & - & - & - & - & - & - \\
\hline Hematite & - & - & - & - & - & 10 & - & - & - & - \\
\hline Goethite & - & - & - & - & - & 10 & - & - & - & - \\
\hline Albite & 5 & 7 & 8 & 4 & 6 & - & - & - & 8 & 7 \\
\hline Siderite & - & - & - & - & - & 10 & - & - & - & - \\
\hline Montmorillonite & - & - & - & - & - & - & 10 & 12 & - & 7 \\
\hline
\end{tabular}

The XRD patterns of all whole-rock samples, which were obtained following the method of Brown and Brindley (1984), indicate the predominating presence of kaolinite and quartz, with minor muscovite or illite. Iron mineral peak was observed only in one sample, indicating incorporation of hematite in the clay minerals. Smectite and montmorillonite are present in trace amounts in some of the samples. Identification of secondary minerals was difficult, because their peaks tended to be obscured by the greater peaks of the major minerals kaolinite and quartz. However there are differences in bulk mineral compositions between the individual sediments (Table 1). For example, the kaolinite content varies from $22 \mathrm{wt} \%$ for Enu 2.5 to $30 \mathrm{wt} \%$ for Enu1.4, with samples much richer in quartz being poorer in kaolinite. The samples contain high amounts of kaolinite, with two of the samples consisting of smectite. All of the sediment samples contain only small amounts of feldspar and calcite. All sediments are, therefore, rich in kaolinite and quartz, which indicate that they are derived mainly from felsic sources. The minor illite and illite-weathered products, such as smectite and chlorite present in some samples, and the low feldspar abundance, suggest a contribution from basic sources. The felsic sediments are derivatives of granitic basement rocks, whereas the basic component is derived from the basic schists probably of the basement from the Oban masif (Cullers, 1994a). 


\section{Paleoclimatic Significance of Clay Mineral Assemblages From Mamu Formation}

Clay minerals are used extensively in different scientific aspects. The latest application is in paleoclimate determination. Based on structural and chemical compositions, the clay minerals susceptibility varies. Clay mineral assemblages identified in selected locations of the Southeastern Nigeria located within the Lower Benue Trough of the Mamu Formation are Kaolinite, Muscovite-Illite and Montmorillonite. Each of this is formed under different environmental and chemical conditions that can help us by using them to interpret depositional/climate condition. Clay minerals in sediments can be useful indicators of paleoclimatic conditions, particularly when the sedimentary basins are small. Our paleoclimatic reconstruction mainly uses the systematic data obtained from southeastern Nigeria clay mineral association within the Lower Benue Trough. The mineralogy of the clay analyses were considered when interpreting the climatic changes within the Lower Benue Trough, southeastern Nigeria, in addition, the minor and major element concentrations were considered especially the cation exchange capacity which reveals the amount of smectitic layers within the clay fraction of the bulk samples.

According to Churchman (2000), the two layer/three layer clay mineral ratio is mainly controlled by climate. Therefore, it is easy to recognize between warm and humid conditions typical for kaolinite formation or dry seasons, specific for illite or smectite formation. Furthermore, the formation of kaolinite is favoured by an acidic conditions, and high leaching environments. Conversely, relatively low or no leaching environment and conditions under neutral to low alkaline $\mathrm{pH}$ favour the formation of montmorillonite and three-layer clay minerals.

The given data in Table 1 presents the clay types and non clay types in the sediments and their distribution in area under study. Kaolinite covered a range of $22-45 \%$. The presence of kaolinite in the sediments along the well exposed road cuts from the King Petrol Station up to the Miliken Hills and the absence of illite, smectite and montmorrilonite is interesting. It can be interpreted to be as the result of climate changes/depositional condition (shallow water) or erosional rate and the composition of the initial provenance rocks. Field investigation supports the idea of the first suggestion. Therefore, it is inferred wet climate during its deposition (Table 1, Enu. 1.1-1.5). Kaolinite is favoured by weathering or hydrothermal alteration of aluminosilicate minerals. Thus, rocks rich in feldspar commonly weather to kaolinite. In order to form, ions like $\mathrm{Na}, \mathrm{K}, \mathrm{Ca}, \mathrm{Mg}$, and Fe must first be leached away by the weathering or alteration process. This leaching is favoured by acidic conditions (low $\mathrm{pH}$ ). Granitic rocks, because they are rich in feldspar, are common source for kaolinite. Kaolinite, because it does not absorb water, does not expand when it comes in contact with water, thus, kaolinite is the preferred type of clay for the ceramic industry.

Muscovite-Illite percentages ranges from 5-10\%. Its value increased in the claystone deposit at the left bank of River Ekulu near the bridge to Onyeama mine, around Iva Valley and along Enugu Port Harcourt in Enugu State (Table 1, Enu.2.1-2.5). This subject can be due to conversion of kaolinite and montmorillonite (Bruce, 1984) or involvement of mixed layer to generate more illite. Illite is generally a group name for nonexpanding, clay sized, dioctahedral, micaceous minerals. It is structurally similar to muscovite in that its basic unit is a layer composed of two inward-pointing silica tetragonal sheets with a central octahedral sheet. However, illite has on average slightly more $\mathrm{Si}, \mathrm{Mg}, \mathrm{Fe}$, and water and slightly less tetrahedral $\mathrm{Al}$ and interlayer $\mathrm{K}$ than muscovite. Formation of illite is generally favoured by alkaline conditions and by high concentrations of $\mathrm{Al}$ and $\mathrm{K}$. The illite clays have a structure similar to that of muscovite, but it is typically different in alkalies, with less $\mathrm{Al}$ substitution for Si. Because of possible charge inbalance, $\mathrm{Ca}$ and $\mathrm{Mg}$ can also sometimes substitute for $\mathrm{K}$. The $\mathrm{K}, \mathrm{Ca}$, or $\mathrm{Mg}$ interlayer cations prevent the entrance of $\mathrm{H}_{2} \mathrm{O}$ into the structure. Thus, illite clays are non-expanding clays.

Montmorrilonite ranges from $7-10 \%$ and one of the least main clay components. Its presence marked terrestrial-non marine environment. Smectites commonly result from the weathering of basic rocks. Smectite formation is favoured by level to gently sloping terrains that are poorly drained, mildly alkaline (such as in marine environments), and have high $\mathrm{Si}$ and $\mathrm{Mg}$ potentials. Other factors that favour the formation of smectites include the availability of $\mathrm{Ca}$ and the paucity of $\mathrm{K}$. Poor drainage is necessary because otherwise water can leach away ions (e.g Mg) released in the alteration reactions. Smectites are used as fillers, carrier and absorbent. The most important aspect of the smectite group is the ability for $\mathrm{H}_{2} \mathrm{O}$ molecules to be absorbed between the T$\mathrm{O}-\mathrm{T}$ sheets (tetrahedral-octahedral-tetrahedral), causing the volume of the mineral to increase when they come in contact with water. Thus, the smectites are expanding clays. The most common smectite is montmorillonite which is characterized of dry region.

\section{Conclusions}

The present study revealed that clay mineral distribution in different locations of the Lower Benue Trough indicated individual trends. Illite percentage was increased from Enu.1.1-1.5 to Enu.2.1-2.5 due to kaolinite - montmorillonite degradation or most probably dry and terrestrial climate dominant. Kaolinite 
presence indicates wet/tropical climate in the Mamu Formation more also with the presence of montmorillonite in Enu 2.1- 2.5 can be indicating a non-marine/terrestrial condition. Therefore, clay mineral assemblage in this part of the world is owning to climate-depositional condition. It seems diagenetic processes are less important. Thus climate factor must be considered as possible factor in monitoring observed clay types in questionable area.

The high dominance of quartz in the clay deposits explains its grittiness and also suggests the clay to be of residual origin.

\section{Reference}

[1]. Agumanu, A.E. (1989) The Abakaliki and Ebony Formations: subdivisions of the Albian Asu River Group in the southern Benue Trough, Nigeria. Journal African Earth Sciences,9,pp, 195-207.

[2]. Akande, S.O. and Muche, A. (1989) Mineralogical, textural and paragenetic studies of the lead zinc-zinc-copper mineralization in the lower Benue Trough (Nigeria) and their genetic implications. Journal of African Earth Sciences,9,pp.445-456.

[3]. Akande, S.O., Hoffknecht, A. and Erdunann, B.D. (1992) Rank and petrolographic composition of selected Upper Cretaceous and Tertiary coals of Southern Nigeria. International Journal Coal Geology,20,pp.209-224.

[4]. Brown, G. and Brindley, G. W. (1984) X-ray diffraction procedures for clay mineral identification. Crystal Structures of Clay Minerals and Their X-ray Identification (Brindley, G. W. and Brown, G., eds.), Mineral. Soc., London, Monogr. 5, 305-360.

[5]. Churchman, G.J. (2000) The alteration and formation of soil minerals by weathering. In Handbook of soil Science (Summer, M.E., ed.). CRC Press New York, 1, F3-27.

[6]. Cullers, R. L. (1994a) The chemical signature of source rocks in size fractions of Holocene stream sedimentderived from metamorphic rocks in the wet mountains region, Colorado, USA. Chem. Geol. 113, 327- 343.

[7]. Elueze, A.A. (1988) Promoting the development and exploitation of mineral resources in Nigeria. In: Proceedings of the first mining in Nigeria conference and workshop, NIMAMOP. Fed. Min. of Solid Minerals, Abuja,pp,9-22.

[8]. Elueze, A.A. and Bolarinwa, A.T. (2001) Appraisal of the residual and sedimentary clays in part of Abeokuta area, southwestern Nigeria, Journal of Mining and Geology,35(2),pp.117-124.

[9]. Elueze, A.A. and Bolarinwa A.T. (1995) Assesment of functional application of lateritic clay bodies in Ekiti environ, Southwestern Nigeria, Journal of Mining and Geology, 31(1),pp.79-87.

[10]. Elueze, A.A., Ntekim, E.E. and Ekwere, S.J. (1999) compositional and industrial assessment of clay bodies in Itu area, southeastern Nigeria. Journal of mining and Geology, 31 (1), pp. 79-87.

[11]. Emofurieta, W.O., Ogundimu, T.O. and Imeokparia, E.G. (1994) Mineralogical, geochemical and economic apprassal of clay and shale deposits in southwestern and northwestern Nigeria. Journsl of mining and Geology, 30 (2), pp. 151-159.

[12]. Holmes, A. (1951) The sequence of Precambrian orogenic belts in South and central Africa. Proceed.18th Internat. Geol. Congr. London 1948, 14, 254-269, London.

[13]. Koeberl, C. (1993) Instrumental neutron activation analysis of geochemical and cosmochemical samples:a fast and reliable method for small sample analysis. Journal Radioanalytical Nuclear Chemistry 168, 37-52.

[14]. Krönberg, B. I., Fyfe, W. S., Leonardos, O. H. and Santos, A. M. (1979) The chemistry of some Brazilian soils: element mobility during intense weathering. Chem. Geol. 24, 211-229.

[15]. MacDonald, R. (1966) Uganda Geology map. Rep. Geol. Surv. Uganda, Entebbe.

[16]. McConnell, R. B. (1959) The Buganda Group, Uganda,East Africa. 20th Internat. Geol. C Congr. Mexico (1956) Assoc. African Geol. Surv., 163-174, Mexico City.

[17]. McGill, M. (1965) Clays in Uganda. Rep. Geol. Surv. Uganda, Entebbe, 150 pp.

[18]. McLennan, S. M. (1989) Rare earth elements in sedimentary rocks: influence of provenance and sedimentary processes. Geochemistry and Mineralogy of Rare Earth Elements (Lipin, B. R. and McKay, G. A., eds.), Rev. Mineral. 21, 169-200.

[19]. McLennan, S. M. (1993) Weathering and global denudation. J. Geol. 101, 295-303. McLennan, S. M. and

[20]. Nesbitt, H. W. and Young, G. M. (1982) Early Proterozoic climates and plate motions inferred from major element chemistry of lutites. Nature 299, 715-717.

[21]. Nesbitt, H. W. and Young, G. M. (1984) Prediction of some weathering trends of plutonic and volcanic rocks based on thermodynamic and kinetic considerations. Geochim. Cosmochim. Acta 48, 1523-1534.

[22]. Nesbitt, H. W. and Young, G. M. (1989) Formation and diagenesis of weathering profiles. J. Geol. 97, 129-147.

[23]. Nesbitt, H. W. and Young, G. M. (1996) Petrogenesis of sediments in the absence of chemical weathering:effects of abrasion and sorting on bulk composition and mineralogy. Sedimentology 43, 341-358.

[24]. Nesbitt, H. W., Markovics, G. and Price, R. C. (1980)Chemical processes affecting alkalis and alkali earths during continental weathering. Geochim. Cosmochim. Acta 44, 1659-1666.

[25]. Nesbitt, H. W., Young, G. M., McLennan, S. M. and Keays, R. R. (1996) Effects of chemical weathering and sorting on the petrogenesis of siliciclastic sediments, with implications for provenance studies. J. Geol. 104, 525-542.

[26]. Nton, M.E. and Elueze, A.A. (2005) Compositional characteristics and industrial assessment of sedimentary clay bodies in part of eastern Dahomey Basin, southwestern Nigeria. Journal of Mining and Geology, 41(2), pp. 259-284

[27]. Obaje N. G. (2009). "The Benue Trough". Geology and Mineral Resources of Nigeria. Springer. p. 57. ISBN 3-540-92684-4.

[28]. Petters SW(1982) Central West African Cretaceous-Tertiary benthic foraminifera and stratigraphy. Palaeontographica Abt A 179:1104

[29]. Puchelt, H. (1972) Barium. Handbook of Geochemistry (Wedepohl, K. H. et al., eds.), 56B1-56O2, Springer,Berlin.

[30]. Reimold, W. U., Koeberl, C. and Bishop, J. (1994) Roter Kamm impact crater, Namibia: Geochemistry of basement rocks and breccias. Geochim. Cosmochim. Acta 58, 2689-2710.

[31]. Reyment, R.A. (1965) Aspects of the geology of Nigeria. Ibadan University Press, Ibadan, Nigeria. 133p.

[32]. Schultz, L. G. (1964) Quantitative interpretation of mineralogical composition from X-ray and chemical data for the Pierre shale. U.S. Geol. Surv. Prof. Pap. 391-C, 33 pp.

[33]. Simpson, A. (1954) The Nigerian coalifield. The geology of parts of Onitsha, Owerri and Benue Provinces. Bulletin Geological survey, Nigeria, $24(8), 85 \mathrm{pp}$.

[34]. Taylor, S. R. and McLennan, S. H. (1985) The Continental Crust: Its Composition and Evolution. Blackwell, Oxford, 312 pp.

[35]. Taylor, S. R. and McLennan, S.H. (1995) The geochemical evolution of the continental crust. Rev. Geophys. 33, 241-265.

[36]. Uma K.O. (1998) The Brine fields of the Benue Trough, Nigeria: a comparative study of geomorphic. Tectonic and hydrochemical properties. Journal Africa earth sciences, 26, pp. 261-275. 
[37]. Wronkiewicz, D. J. and Condie, K. C. (1987) Geochemistry of Archean shales from the Witwatersrand Super group, South Africa: source-area weathering and provenance. Geochim. Cosmochim. Acta 51, 2401-2416.

[38]. Wronkiewicz, D. J. and Condie, K. C. (1989) Geochemistry and provenance of sediments from the Pongola Supergroup, South Africa: evidence for a $3.0 \mathrm{Ga}$ old continental craton. Geochim. Cosmochim. Acta 53, 1537-1549.

[39]. Wronkiewicz, D. J. and Condie, K. C. (1990) Geochemistry and mineralogy of sediments from the Ventersdorp and Transvaal Super groups, South Africa: cratonic evolution during the early Proterozoic. Geochim. Cosmochim. Acta 54, 343-354.

[40]. Zaborski, P.M. (1998) A review of the Cretaceous System in Nigeria, African Geoscience Review, 5(4), pp. 385-483 